Ensino, Saúde e Ambiente - v. 14 n. esp. (2021): Dossiê Paulo Freire para além dos 100 anos:

construir utopias, transformar a realidade.

Editorial

ENSINO, SAÚDE E AMBIENTE

\title{
Carta das editoras
}

O dossiê Paulo Freire para além dos 100 anos: construir utopias, transformar a realidade comemora o centenário de nascimento de Paulo Freire. Com ele, iniciamos também os festejos do $15^{\circ}$ ano de publicação da revista Ensino Saúde e Ambiente (ESA), a serem completados em 2022.

A ESA começou com o sonho, a dedicação e o trabalho árduo da professora Rose Latini, em agosto de 2008. Foram muitos caminhos até chegarmos ao Programa de PósGraduação em Ensino de Ciências da Natureza na Universidade Federal Fluminense, e com essa editoria feita pelas mãos de quatro mulheres. Desde então, a ESA vem se tornando um periódico cada vez mais interdisciplinar. Festejaremos seu aniversário afirmando, com o dossiê, seu sentido contracolonizador, que se dá pela interpelação dos movimentos sociais ao exercício da produção de conhecimento dos campos acadêmicos.

É assim que o objetivo que por anos definiu a ESA — “divulgação de artigos científicos resultantes de pesquisas e de relatos de experiências originais sobre temas que envolvem o Ensino de Ciências em espaços formais e não formais. Sem perder de vista, evidentemente, a precípua finalidade de integração de pesquisadores que atuam na interface ensino, saúde e ambiente" - começa a ser reescrito, trazendo à cena o sentido de que uma revista cujo tema gerador é a educação precisa, antes de tudo, encontrar aquelas/aqueles que têm sido colocadas/os à margem para, enfim, produzir sentidos de educação que encontrem a nossa realidade. Este é o nosso inédito-viável.

Portanto, o dossiê Paulo Freire para além dos 100 anos: construir utopias, transformar a realidade é, para nós, um marco na direção do diálogo com aquelas e aqueles das/os quais a universidade só havia se aproximado até então para tomar como objeto. Esse é um momento importante da ESA, porque Paulo Freire é autor inconformado, cuja obra e o legado trazem as marcas das/os oprimidas/os. Paulo Freire se deixou interpelar pelas feministas negras americanas, pelas trabalhadoras/es brasileiras/os, pelas camponesas/es de diversos lugares do mundo por onde passou. Alguns desses lugares são de África, onde aprendeu com as obras e o legado de muitas e muitos revolucionárias/os. Assim, o dossiê 
Ensino, Saúde e Ambiente - v. 14 n. esp. (2021): Dossiê Paulo Freire para além dos 100 anos: construir utopias, transformar a realidade.

\section{Editorial}

revela as várias possibilidades de caminho da obra e do legado de Freire, mas todas se encontram no inconformismo com a opressão e na esperança que se forma na luta cotidiana.

Gratidão a Inny Aciolly, Celso Sánchez, Samuel Urban e Bruno Monteiro, pela concepção do dossiê. Gratidão a Sergio Sant'Ana por sua operacionalização. Somamo-nos a ela e a eles nesse momento em que vivemos a dor das mais de 600 mil vidas perdidas pela pandemia de covid19, para dedicarmos esta publicação a todes que entendem que "a palavra muda o mundo", que "a prática preconceituosa de raça, de classe, de gênero ofende a substantividade do ser humano e nega radicalmente a democracia”. Seguimos nos inspirando em Paulo Freire com a esperança da luta por dias nos quais não teremos que conviver com um governo de morte. Agradecemos também às autoras e autores que contribuíram para a construção do dossiê e à FAPERJ, pelo financiamento que garante sua publicação.

E nós, essas quatro mulheres, caminharemos inventando esta editoria pelas práticas antirracistas, antissexistas, antimachistas, anticapacitistas e, como nos ensina Paulo Freire, pela boniteza da vida! Viva Paulo Freire, sua obra e seu legado!

Amorosamente,

Luiza Oliveira, Maria Bernadete Pinto dos Santos, Maylta Brandão dos Anjos e Rose Latini

No quase verão de 2021 